\title{
A ESCRITA COMO CONTRAPONTO AO ESQUECIMENTO: TESTEMUNHO E MEMÓRIA TRAUMÁTICA EM COVA 312
}

\author{
[Writing as a Counterpoint to Forgetting: Testimony and Traumatic \\ Memory in Cova 312]
}

\author{
Janaína Buchweitz e Silva ${ }^{1}$ \\ Claudia Lorena Vouto da Fonseca ${ }^{2}$
}

Resumo: O presente artigo parte da obra da jornalista e escritora Daniela Arbex, intitulado Cova 312, para tratar de questões como testemunho e memórias traumáticas oriundas da ditadura brasileira. Para tanto, utiliza-se de referencial teórico proposto por Agamben (2008) para debater a questão do testemunho, e de Benjamin (1996) e Gagnebin (2009) para discutir a escrita da história no tempo presente. Sendo o livro composto por dezenas de testemunhos de militantes que vivenciaram o período da ditadura, entende-se que também a autora opera enquanto uma testemunha da história do Brasil, ao dar escuta aos relatos traumáticos dos sobreviventes do período militar. Os testemunhos propiciam uma reflexão sobre passado e memória, em que questões como acesso à verdade e à justiça se entrelaçam às possibilidades do testemunho e à escrita da história no tempo presente.

Palavras-chave: história; memória; testemunho; ditadura.

Abstract: This article starts from the work of the journalist and writer Daniela Arbex, entitled Cova 312, to address issues such as testimony and traumatic memories from the Brazilian dictatorship. For that, it uses the theoretical framework proposed by Agamben (2008) to debate the question of testimony, and Benjamin (1996) and Gagnebin (2009) to discuss the writing of history in the present time. Being the book composed by dozens of testimonies from militants who experienced the dictatorship period, it is understood that the author also operates as a witness to the history of Brazil, by listening to the traumatic reports of survivors of the military period. The testimonies provide a reflection about past and memory, in which issues such as access to truth and justice are intertwined with the possibilities of testimony and the writing of history in the present time.

Keywords: history; memory; a testimony; dictatorship.

\footnotetext{
1 Doutoranda em Letras na Universidade Federal de Pelotas - UFPel. E-mail: janaesilva@yahoo.com.br 2 Professora Adjunta do Centro de Letras e Comunicação da Universidade Federal de Pelotas-UFPel. E-mail: fonseca. claudialorena@gmail.com
} 
A jornalista Daniela Arbex publicou no ano de 2002 uma série de reportagens para o jornal Tribuna de Minas sobre a penitenciária de Linhares, uma importante prisão política do período da ditadura militar brasileira. Das diversas histórias que conheceu ao longo da reportagem, a do militante gaúcho Milton Soares de Castro foi a que mais chamou sua atenção. O rapaz iria participar de uma guerrilha que não chegou a ocorrer, a chamada Guerrilha do Caparaó, e acabou tornando-se preso político da penitenciária de Linhares, local em que permaneceu por menos de um mês, tendo sido o único preso político encontrado morto nas dependências desse presídio. Arbex reconstrói parte da vida de Milton, tanto dentro quanto fora da prisão, e sua investigação contribui para a elucidação de um dos muitos casos de desaparecimento que ocorreram durante o período ditatorial brasileiro, já que depois de sua morte o corpo de Milton desapareceu de dentro da prisão. A versão oficial atestou suicídio, e coube à autora, quase quatro décadas depois, a elucidação do caso, através de sua investigação.

Composto pela biografia do preso político Milton, Cova 312 contém ainda histórias de diversos outros presos políticos com os quais ele conviveu e com quem a repórter teve oportunidade de dialogar ao longo de seu trabalho investigativo. Através dos testemunhos coletados, foi possível reconstituir parte de sua vida e também elucidar o paradeiro de seu corpo, que foi descoberto pela repórter em uma cova rasa, em um cemitério mineiro, identificada apenas pelo número, 312, o que deu título ao livro. Para reconstruir os dias de Milton na prisão, a jornalista buscou uma série de depoimentos de outros presos políticos e também de militares da prisão de Linhares, bem como de médicos legistas que atestaram o óbito de Milton na ocasião, além de familiares e amigos, o que contribuiu para o resgate da história e da memória do biografado: "Para Edelson, a descoberta da tribuna não é apenas um resgate da história, mas da memória do militante. 'Obrigado. Nós esperamos por 35 anos', disse, em lágrimas." (ARBEX, 2015, p.282). Além disso, a autora oportuniza a toda a sociedade brasileira uma nova versão sobre um episódio que compõe um importante momento histórico do Brasil, que foi o período da ditadura, que a própria jornalista denomina "reconstrução da verdade" (ARBEX, 2015, p.29). A obra é ainda permeada por significativa quantidade de fotografias, feitas pela repórter e sua equipe, que vão desde reproduções de registros das dependências da penitenciária de Linhares, a fotos de documentos, como pareceres e documentos oficiais dos mais diversos, além de fotos do arquivo pessoal da família de Milton e de outros presos políticos, registros da captura de perseguidos políticos na serra do Caparaó, fotos de jornais, bilhetes, cadernos e documentos pessoais de militantes.

O livro-reportagem de Arbex é fruto de sua investigação e contribui para a divulgação e manutenção da memória brasileira sobre o período da ditadura. Livro-reportagem, e não romance-reportagem, como talvez se pudesse pensar em um primeiro momento, embora seja tênue a linha que separa as duas categorias no caso de Cova 312.

Nesse sentido, considerando o estreito vínculo da obra objeto de nossa análise com o jornalismo investigativo, e não apenas no que concerne à formação da autora, mas pensando também sua constituição, nos remetemos ao estudo de Rildo Cosson (2001) sobre o romance-reportagem, no qual este se debruça sobre as relações entre literatura e jornalismo, entre narrativa e reportagem, no intuito de reivindicar o seu estabelecimento como gênero autônomo "situado nas fronteiras de dois discursos: o literário e o jornalístico" (p. 
9). Chamando a atenção para o fato de que a literatura em relação estreita com o jornalismo, cuja ocorrência foi marcante nos anos 70, segue atual, Cosson constata que essa forma de ocorrência do literário sofre algumas modificações, atualizando-se, e que haveria que sistematizar a forma. É o que ele faz ao tratar desse "modo mais específico de narrar que parece ser, também, a imagem de sua época" (p.12).

No entanto, se nos anos 70 do século passado essa produção se caracterizava marcadamente por ficcionalizar fatos e personagens reais, buscando subsídios na reportagem/ crônica jornalística ou, em muitos casos3, buscando driblar a censura com narrativas cujo objetivo era dar a conhecer os fatos ocorridos no período da ditadura civil-militar brasileira, resistindo e denunciando as silenciadas atrocidades cometidas por esse regime, elas compartilham esse espaço com obras que se caracterizavam por estabelecer uma relação mais tênue com o literário e mais intensa com o jornalismo. Essa vertente se expande nos anos pós-ditadura, ampliando e aprofundando temas, dadas as possibilidades do suporte livro em contraste com as limitações do jornalismo impresso cotidiano. A essa vertente denominamos livro-reportagem ${ }^{4}$.

De qualquer forma, considerando-se as relações entre jornalismo e literatura, ainda nos anos 70 observamos a ocorrência de uma série de obras heterogêneas, a partir do enfoque, tema ou opções/estratégias narrativas e de construção, do tratamento dado à verdade factual (ou testemunhal, em muitos casos), todas elas caracterizadas, em um sentido amplo, por estarem presas "a um desejo de veracidade, a um compromisso com a atualidade e com a referencialidade”. (COSSON, 2001, p.16)

Poderíamos dizer, portanto, que a obra de Daniela Arbex se inscreveria antes na vertente do livro-reportagem que na do romance-reportagem. Cova 312 não se configura como romance-reportagem no sentido mais corrente do termo, apesar do tom narrativo, muitas vezes lírico, pois não ficcionaliza de fato o real, entre outros motivos, porque a narrativa tem seu fluxo interrompido pelas imagens a cada final de capítulo, como a nos lembrar que de reportagem se trata. No entanto, dialoga com o romance-reportagem brasileiro do período ditatorial no sentido em que a partir do dado factual opera como denúncia das atrocidades cometidas no período da ditadura civil-militar no Brasil, dando a conhecer os fatos ocorridos nesse período, operando também no sentido de não deixar que estes sejam esquecidos, aproximando-se, portanto, do gênero romance-reportagem. Há ainda muitos pontos de convergência entre ambas as formas, por exemplo, o impacto da revista Realida$d e$, que Cosson cita como influência para o romance-reportagem, é igualmente citado pelos estudiosos que se dedicam ao estudo do livro-reportagem, os quais também situam Os sertões, de Euclides da Cunha como precursor do gênero no Brasil. O fato é que ambas as formas vinculam-se ao jornalismo e, muitas vezes se confundem e/ou se interpenetram dando espaço a formas intermediárias, rompendo assim as fronteiras entre elas ou entre gêneros.

3 Cosson (2001) destaca que há que se considerar outros fatores determinantes para a ocorrência e disseminação do romance reportagem no Brasil nos anos 70, além da ditadura, entre eles a relação estreita entre literatura e jornalismo, no que concerne à constituição de nossa literatura, seja pela questão suporte ou pela sempre observável ocorrência de formas híbridas; a natureza naturalista da literatura brasileira; o impacto da revista Realidade sobre o mundo jornalístico, considerando-se o tratamento literário dado às suas reportagens, entre outros fatores.

4 Nos moldes em que trata o tema Edvaldo Pereira Lima (2004). 
Mas Cova 312 pode ser entendido, também, e sobretudo, como um livro de memórias de uma repórter investigativa que optou por desenvolver um trabalho atrelado ao período da ditadura, onde as impressões pessoais da autora sobre o tema figuram em destaque. Arbex relata, em determinada passagem da obra, que ao deparar-se em sua rotina de trabalho na Tribuna de Minas com uma notícia sobre indenização às vítimas de tortura deu-se conta da relevância do tema:

Fiquei hipnotizada por aquela notícia. Desde o meu primeiro dia no jornal, eu cobria assuntos ligados aos direitos humanos, minha área prioritária de interesse. Além disso, alimentava o desejo quase secreto de fazer algo relacionado a esse período da história, já que eu nasci nove anos após o golpe militar e só acompanhei o que se passou no Brasil pelos livros. Queria dar minha contribuição como jornalista, mas não sabia de que maneira. (ARBEX, 2015, p.90)

O relato de Arbex demonstra a necessidade da jornalista em participar da história de seu país, o que é feito através da tarefa investigativa que sua profissão lhe propicia, e o resultado final se dá através do ato da escrita, como forma de divulgação da tarefa empreendida enquanto repórter.

Disposta a contar um capítulo inédito da ditadura, iniciei ainda naquele março de 2002 o trabalho de investigação que tinha duas frentes: levantar o que se passou com o único civil da guerrilha do Caparaó até o momento de sua morte e localizar os militantes da cidade que haviam pleiteado reparação junto à Comissão Estadual de Indenização às Vítimas da Tortura. Ambas foram tarefas difíceis. A primeira porque era permeada por silêncio. A outra em função de muitas vítimas do período terem receio de se expor publicamente em uma matéria de jornal. Foi preciso conquistar a confiança de cada uma delas. (ARBEX, 2015, p.95)

A ditadura civil militar brasileira iniciada em 1964 deu lugar a uma série de atrocidades, onde o Estado, sob a alegação de agir em nome da ordem e do bem comum, impôs aos cidadãos uma série de medidas de natureza violenta, nas suas mais variadas formas, sendo a prática de tortura de presos políticos corriqueira dentro das prisões e locais de detenções. Com isso, a violência a que foram submetidos os perseguidos políticos gerou traumas e ficou impregnada na memória da geração que vivenciou aquele período. No entanto, muitos brasileiros e brasileiras das gerações que se seguiram desconhecem boa parte desse episódio da história do Brasil, seja porque foram desestimulados a debaterem sobre o assunto, seja porque existe até os dias de hoje uma espécie de desconforto ao se abordar o tema, além da postura negacionista de parte da sociedade que, entre outros prejuízos, fez com que os resultados do trabalho empreendido pela Comissão Nacional da Verdade ${ }^{5}$ ficassem abaixo das expectativas nele depositadas.

5 Comissão temporária instituída pela Lei 12528/2011, com o objetivo de apurar e esclarecer as violações aos direitos humanos perpetradas pelo Estado brasileiro no período compreendido entre 1946 e 1988, tornando públicas essas ações. A Comissão atuou entre os anos de 2012 e 2014. 
Em um período de forte repressão, onde muitos militantes foram perseguidos, calados, sequestrados, torturados e assassinados, a memória que se produziu se desenvolveu na ordem do trauma ${ }^{6}$. Com isso, muitas experiências não puderam ser simbolizadas pela palavra, seja porque nenhuma palavra alcança a dimensão do que foi experienciado, seja porque muitos foram sequestrados ou mortos, não podendo narrar sua história. A obra de Arbex, nesse sentido, funciona como um registro de parte da história do Brasil, que é dessa forma divulgada e retomada no tempo presente com o intuito de reescrevê-la e também de lutar contra o esquecimento e o silenciamento que permeia o tema da ditadura no país. A autora reconstrói o contexto da ditadura ao longo da narrativa, com uma série de referências e informações sobre aquele período:

Nas celas de Linhares nasceu um vigoroso movimento de resistência contra as atrocidades do regime. O convívio dos estudantes, mantidos juntos nas alas destinadas aos subversivos, levou a uma indesejada troca de informações. Cada novo preso político trazia notícias detalhadas sobre a tortura sofrida em dependências policiais e militares do país. Começava ali uma incômoda dor de cabeça para o Exército após a redação do Documento de Linhares. Escrito dentro da unidade, em 1969, ele foi o primeiro que denunciou detalhadamente a violência no período em que a força disseminou o medo. Os carcereiros e o próprio regime militar nunca entenderam como o material burlou a censura e a segurança para tornar conhecidos internacionalmente os abusos cometidos nos porões da ditadura. (ARBEX, 2015, p.28)

Arbex foca o seu trabalho investigativo na história de Milton, porém ao longo do texto são descritos fatos ocorridos com dezenas de outros presos políticos e participantes do regime, o que foi possível através da imensa quantidade de testemunhos coletados pela jornalista ao longo de seu processo de investigação. No fragmento a seguir, a repórter descreve uma das várias situações de tortura a que os presos políticos eram submetidos durante o período da ditadura:

O motivo que levou Marco Antônio a sofrer uma das piores formas de tortura na ditadura era ainda mais torpe do que a tentativa de fazê-lo entregar endereços de aparelhos ou denunciar nomes de militantes. Em setembro de 1969, teve os braços e as pernas amarrados em uma barra de ferro por simples vingança. Inconformada com o estado físico do jovem, a mãe dele, Maria Luiza Azevedo Meyer, procurou a esposa do comandante que presidia o inquérito para pedir clemência. Penalizada diante da viúva que criou praticamente sozinha os dez filhos, a mulher do oficial tentou interceder junto ao marido, mas o efeito foi contrário. O estudante foi duramente perseguido. (ARBEX, 2015, p.131)

Os relatos de casos de tortura se sucedem na obra de Arbex, e isso só foi possível porque há aqueles que sobreviveram para narrar o que vivenciaram, ao contrário do que

6 Pensamos trauma a partir da perspectiva de Márcio Selligman-Silva (2002; 2008). 
ocorreu com Milton. Os depoentes relataram uma série de episódios, dentre eles uma aula de tortura para militares em que os presos foram submetidos como cobaias:

- Hoje vamos ensinar aos senhores alguns métodos de interrogatório que têm funcionado bem na missão de combate aos crimes cometidos contra o país por terroristas - disse o tenente segurando nas mãos uma vareta semelhante às usadas em salas de aula por professores.

Ao iniciar sua fala, o tenente Ailton determinou que o projetor fosse ligado. Os slides continham desenhos de tortura. As cenas deveriam ser reproduzidas ali, naquele auditório, com os jovens escolhidos para serem cobaias humanas. O cabo Mendonça, o soldado Marcolino, além dos sargentos Andrade, Oliveira, Rossoni e Rangel foram chamados para ajudar na "exposição". (ARBEX, 2015, p.153)

A autora narra o trauma experienciado por quem foi submetido à sessão de tortura, e o faz também através da escuta dos testemunhos de sobreviventes:

O militante tinha certeza de que jamais seria o mesmo após aquele episódio. Acuado como um animal numa caçada, ele teve confiscada a sua humanidade. Estava de novo no circo. Não naquele mágico da sua infância, mas em um no qual era exibido como uma fera por domadores sem escrúpulos.

De vez em quando, o som de risadas cortava o desconcertante silêncio que pairava no ar. As cenas de barbárie, porém, foram tão perturbadoras que, durante a sessão, um sargento não aguentou ficar na sala. Outro vomitou. (ARBEX, 2015, p.154)

Durante quase quatro décadas, a família do militante conviveu com a versão oficial de suicídio fornecida pelos militares. Edelson, irmão de Milton que também foi integrante do Movimento Nacional Revolucionário (MNR) e preso político, recebeu nas dependências do Exército a informação sobre a morte do irmão, uma versão da história que a família nunca aceitou:

- Infelizmente, a informação que trago não é boa. Seu irmão, Milton, se matou hoje de manhã em Juiz de Fora. Meus pêsames. Mas vamos fazer de tudo...

O pintor interrompeu o comandante:

- isso não foi suicídio, senhor. Assassinaram o meu irmão - gritou o preso.

- Rapaz, você não sabe do que está falando - cortou o oficial. (ARBEX, 2015, p.37) 
Coube à Arbex contestar a versão oficial do Estado sobre as causas da morte de Milton, trinta e cinco anos após sua morte. Segundo Walter Benjamin (1996), para um melhor entendimento do passado, deve-se romper com a empatia para com os vencedores, que carregam junto a si a herança de todos aqueles que venceram antes. O autor defende que se faz necessário "escovar a história a contrapelo", com o intuito de investigar os sentidos que estão encobertos pelo discurso histórico dito oficial, ou seja, buscar o que não é dito no discurso dos vencedores e dominadores, o que foi feito pela autora ao longo de toda sua investigação. A jornalista retoma a participação dos irmãos no movimento de resistência ao regime e, em uma espécie de biografia, busca reconstruir suas vidas, dando, evidentemente, um maior destaque para a história de Milton:

Milton foi quem convenceu o irmão Edelson a abraçar a causa contra o regime. Apesar da pouca instrução formal - havia estudado apenas o primário - ele sempre se interessou por política. E foi através da militância no PCdoB que se aproximou de Gregório. A percepção de um país com poucas oportunidades para as camadas populares sempre incomodou o operário. Por isso, quando as primeiras notícias sobre o golpe chegaram ao Rio Grande do Sul, o filho de Santa Maria já discutia a transformação das relações de propriedade na busca pela igualdade social. Apresentado em uma reunião clandestina às ideias de Karl Marx e Friedrich Engels, começou a formar as suas em relação à luta de classes. Após o contato com a esquerda de Porto Alegre, deixou de ser um observador da realidade para assumir a militância contra as forças de repressão. (ARBEX, 2015, p.46)

No entanto, a biografia de Milton é reconstituída a partir do testemunho de terceiros, dado que não sobreviveu para narrar suas experiências. As dificuldades do testemunho são investigadas por Giorgio Agamben na publicação intitulada O que resta de Auschwitz (2008), na qual o autor reflete sobre a origem do termo testemunha, partindo do latim e do grego, destacando que no latim existem dois termos para representar a testemunha: testis e superstes. O termo testis seria a origem do termo testemunha por nós atualmente utilizado, e seu significado seria "o terceiro", aquele que se põe como o terceiro em um litígio entre outros dois. Já o termo superstes "indica aquele que viveu algo, atravessou até o final um evento e pode, portanto, dar testemunho disso." (AGAMBEN, 2008, p.27). No idioma grego, testemunha é martis (mártir), que deriva de um verbo que significa "recordar", e de onde os primeiros padres derivaram o termo martirium, "a fim de indicar a morte dos cristãos perseguidos que, assim, davam testemunho de sua fé.” (AGAMBEN, 2008, p.35). Para Agamben, o testemunho de um sobrevivente se dá a partir de uma lacuna, pois o sobrevivente daria um pseudotestemunho, considerando-se que os não sobreviventes seriam os únicos detentores de um testemunho integral:

A testemunha comumente testemunha a favor da verdade e da justiça, e delas a sua palavra extrai consistência e plenitude. Nesse caso, porém, o testemunho vale essencialmente por aquilo que nele falta; contém, no seu centro, algo intestemunhável, que destitui a autoridade dos sobreviventes. As "verdadeiras" teste- 
munhas, as "testemunhas integrais" são as que não testemunharam, nem teriam podido fazê-lo. São os que "tocaram o fundo", os muçulmanos, os submersos. Os sobreviventes, como pseudotestemunhas, falam em seu lugar, por delegação: testemunham sobre um testemunho que falta. Contudo, falar de uma delegação, no caso, não tem sentido algum: os submersos nada têm a dizer, nem tem instruções ou memórias a transmitir. Não tem "história", nem "rosto" e, menos ainda, "pensamento". Quem assume para si o ônus de testemunhar por eles, sabe que deve testemunhar pela impossibilidade de testemunhar. Isso, porém, altera de modo definitivo o valor do testemunho, obrigando a buscar o sentido em uma zona imprevista. (AGAMBEN, 2008, p.43)

Para designar aquele que não consegue narrar, o prisioneiro que é também privado da linguagem, Agamben trabalha com o conceito de muçulmano, desenvolvido a partir do termo Muselmann, originário dos campos de concentração e empregado para denominar aquele que:

havia abandonado qualquer esperança e que havia sido abandonado pelos companheiros, já não dispunha de um âmbito de conhecimento capaz de lhe permitir discernimento entre bem e mal, entre nobreza e vileza, entre espiritualidade e não espiritualidade. Era um cadáver ambulante, um feixe de funções físicas já em agonia. Devemos, por mais dolorosa que nos pareça a escolha, excluí-lo da nossa consideração. (AMÉRY apud AGAMBEN, 2008, p.49).

Discorrendo sobre as diferentes origens para o termo Muselmann, o autor aponta que além dos problemas relativos à sua etimologia, também há o problema quanto ao seu uso no campo semântico e disciplinar, já que pode ser percebido partindo da ética, da política ou da antropologia, citando apenas alguns exemplos. Com isso, Agamben destaca a indefinição característica do termo, em que: "não só a humanidade e a não-humanidade, mas também a vida vegetativa e a de relação, a fisiologia e a ética, a medicina e a política, a vida e a morte transitam entre si sem solução de continuidade." (AGAMBEN, 2008, p.56). De certa forma, o termo muçulmano, frequentemente utilizado por Primo Levi e Giorgio Agamben ao referirem-se às vítimas do holocausto, também pode ser utilizado para designar aquele que foi encarcerado, abandonado e assassinado, como ocorreu com Milton, aquele de quem o testemunho jamais será conhecido, assim como as circunstâncias reais de sua morte. Nesse sentido, podemos entender Milton como uma espécie de muçulmano, já que teve sua vida aniquilada pelo Estado e, enquanto testemunha integral, não pode narrar o que viveu.

Para Agamben, o muçulmano é o intestemunhável. Sobre quem seja o sujeito do testemunho, o autor defende que:

Poder-se-ia dizer, à primeira vista, que seja o homem - o sobrevivente - que dá testemunho do não-homem, do muçulmano. Se, porém, o sobrevivente testemunha pelo muçulmano - no sentido técnico de "por conta de" ou "por delegação" ("falamos nós em lugar deles, por delegação"), então, de algum modo, segundo 
o princípio jurídico pelo qual os atos do delegado são imputados ao delegante, é o muçulmano que dá testemunho. Contudo, isso significa que quem de fato dá testemunho no homem é o não-homem, ou seja, que o homem não é senão o mandatário do não-homem, aquele que lhe empresta a voz. Ou então, que não existe titular do testemunho; que falar, dar testemunho significa entrar em um movimento vertiginoso, em que algo vai a pique, se dessubjetiviza integralmente e emudece, e algo se subjetiviza e fala, sem ter - propriamente - nada a dizer ("falo de coisas[...] que eu mesmo não experimentei"). Algo no qual quem é sem palavra leva o falante a falar, e quem fala carrega em sua própria palavra a impossibilidade de falar, de modo que o mudo e o falante, o não-homem e o homem ingressam - no testemunho - em uma zona de indistinção na qual é impossível estabelecer a posição de sujeito, identificar a "substância sonhada" do eu e, com ela, a verdadeira testemunha. (AGAMBEN, 2008, p.124)

Já Jeanne Marie Gagnebin (2009) entende que, sendo o exercício da palavra um dos nossos campos de atividade, aqueles que não vivenciaram o terror ou o massacre têm a tarefa de reestabelecer o espaço simbólico onde se possa articular o que ela denomina de um "terceiro", que seria "aquele que não faz parte do círculo infernal do torturador e do torturado, do assassino e do assassinado, aquilo que, "inscrevendo um possível alhures fora do par mortífero algoz-vítima, dá novamente um sentido humano ao mundo" (p.57). Assim, a autora defende uma ampliação para o termo testemunho, que dessa forma abrangeria todo aquele que dá escuta ao outro:

Nesse sentido, uma ampliação do conceito de testemunha se torna necessária; testemunha não seria somente aquele que viu com seus próprios olhos, o histor de Heródoto, a testemunha direta. Testemunha também seria aquele que não vai embora, que consegue ouvir a narração insuportável do outro e que aceita que suas palavras levem adiante, como num revezamento, a história do outro: não por culpabilidade ou por compaixão, mas porque somente a transmissão simbólica, assumida apesar e por causa do sofrimento indizível, somente essa retomada reflexiva do passado pode nos ajudar a não repeti-lo infinitamente, mas a ousar esboçar uma outra história, a inventar o presente. (GAGNEBIN, 2009, p.57)

As circunstâncias da morte de Milton jamais serão conhecidas, porém a investigação de Daniela Arbex proporcionou que se conhecesse outras versões dos fatos, informações relevantes, que inclusive acarretaram na descoberta do corpo, quase quarenta anos após sua morte.

Além de assassinado na prisão, Milton teve seu corpo sequestrado, o que impossibilitou a despedida e comprometeu a elaboração do luto por parte de sua família. Através do testemunho do irmão e da irmã do militante, a autora reconstrói também as dores da mãe do preso político, que nunca se conformou por ter o filho preso pelo regime, e muito menos pelo fato de desconhecer o paradeiro de seu corpo: 
Aos poucos, velhas feridas foram se abrindo. Elas se revelaram na lembrança do choro permanente da mãe todas as vezes que se lembrava do filho "metido nessas coisas de revolução" e com paradeiro desconhecido. Enquanto cozinhava, dona Universina pensava que ele poderia não ter comido nada naquele dia. O pranto dela ficou ainda mais forte quando a notícia de que tinha um filho suicida se espalhou. Embora ela nunca tivesse acreditado nessa versão, não ter um corpo para velar é como se Milton morresse todos os dias. O luto permanente é a sina dos que não conseguem encontrar consolo enquanto persiste a dúvida.

Por isso, a ditadura precisa ser lembrada. Não para falar mais do mesmo, mas para que se possa avançar no levantamento dos casos e na luta pela abertura eficiente e efetiva de nossos arquivos. (ARBEX, 2015, p.334-335)

A narrativa de Arbex diverge do relato oficial, na medida em que as informações coletadas pela repórter confrontaram a versão da história que até então se conhecia, a partir das informações dadas pelos oficiais que eram responsáveis pela penitenciária de Linhares. As descobertas proporcionadas por sua investigação foram bastante reconfortantes para os familiares do preso político Milton:

Após a descoberta da Cova 312, telefonei para Gessi Palmeira Vieira, em Porto Alegre, para revelar o lugar em que seu irmão havia sido enterrado. Durante trinta e cinco anos, o local foi mantido em sigilo pelos militares, tornando-se um dos grandes segredos guardados pela ditadura brasileira.

Ao receber a notícia, Gessi não conteve a emoção:

"O que fizeram com o Milton não se faz nem com um bicho. Ele tinha um ideal, queria mudar o país. Quando soubemos de sua morte, lutamos por muito tempo para que o exército nos entregasse seu corpo. Não tivemos o direito de velar nosso irmão", disse, chorando.

Edelson mostrou-se igualmente comovido.

"Minha mãe sofreu muito com a morte do Milton. Todos nós ficamos marcados. Tínhamos um lema, uma convicção. Ele jamais se mataria. Meu irmão cumpriu seu papel perante o Brasil." (ARBEX, 2015, p.276)

A família de Milton reconhece a importância do trabalho empreendido pela jornalista enquanto resgate de memória e fortalecimento da democracia:

Até que, em 3 de junho, recebi um telefonema de Edelson Palmeira de Castro, irmão de Milton.

"Daniela, a proposta de exumação da ossada, aprovada pela comissão especial, 
reabre uma ferida de trinta e cinco anos. A sua descoberta foi fundamental porque, além de fazer justiça ao Milton, permitiu que soubéssemos, finalmente, onde seu corpo foi colocado. Ao resgatar sua memória, vocês tiraram o véu da dúvida e fortaleceram a democracia. Mas já sofremos muito, e a exumação não vai trazer ele de volta. Preferimos cultivar seu espírito", explicou por telefone. (ARBEX, 2015, p.286)

O resgate da memória do prisioneiro político Milton, proposto pela investigação e pela escuta de Arbex, contribuiu ainda para que parte da história do Brasil fosse contada partindo de outro ângulo, diferente do ponto de vista apresentado pela versão oficial, a do governo e dos militares, mas também contribuiu por trazer uma espécie de conforto para a família, que acabou por receber a informação definitiva sobre o paradeiro de seu corpo e sobre as possíveis circunstâncias de sua morte, o que operou como um resgate de memória:

Conversamos amenidades sobre o voo até que tocamos no motivo principal daquele encontro: Milton e a investigação jornalística que me aproximara dos parentes de quem ele não pôde se despedir.

Talvez por isso, Gessi me visse como uma ponte para o passado. Eu havia resgatado as memórias do militante, e isso nos aproximava como se fôssemos velhas conhecidas. A ausência de Milton me levou até a presença dos seus amores. Estar perto de Gessi e de Edelson era a chance de conhecer os sonhos e os desejos dele. Por isso, naquela sala pequena, nós nos completávamos. (ARBEX, 2015, p.334)

Gagnebin, no ensaio intitulado Verdade e memória do passado), tece algumas considerações sobre a tarefa do historiador que podem ser aplicadas também para a investigação jornalística e consequente escrita literária de Daniela Arbex, na medida em que os relatos divulgados pela jornalista contribuem para uma nova escrita da história, assim como o faz o historiador:

Enquanto Homero escrevia para cantar a glória e o nome dos heróis e Heródoto, para não esquecer os grandes feitos deles, o historiador atual se vê confrontado com uma tarefa também essencial, mas sem glória: ele precisa transmitir o inenarrável, manter viva a memória dos sem-nome, ser fiel aos mortos que não puderam ser enterrados. Sua "narrativa afirma que o inesquecível existe" mesmo se nós não podemos descrevê-lo. Tarefa altamente política: lutar contra o esquecimento e a denegação é também lutar contra a repetição do horror (que, infelizmente, se reproduz constantemente). Tarefa igualmente ética e, num sentido amplo, especificamente psíquica: as palavras do historiador ajudam a enterrar os mortos do passado e a cavar um túmulo para aqueles que dele foram privados. Trabalho de luto que nos deve ajudar, nós, os vivos, a nos lembrarmos dos mortos para melhor viver hoje. Assim, a preocupação com a verdade do passado se completa na exigência de um presente que, também, possa ser verdadeiro. (GAGNEBIN, 2009, p.47) 
Arbex ouviu tanto os oprimidos como os opressores, tendo buscado também o depoimento de militares que trabalharam na penitenciária de Linhares e de médicos que atestaram o óbito de Milton. Buscando a reconstituição do episódio em torno de seu assassinato, a jornalista localizou um dos médicos legistas responsáveis pelo laudo que atestara suicídio, e reproduziu parte do encontro no fragmento a seguir:

- Doutor Orlando, o que o senhor se lembra do dia em que esteve na Penitenciária de Linhares?

- Olha, é aquilo que eu estou te falando. Eu não me lembro de nada. Não tenho nada para afirmar, nem para dizer. Se você falou que pode não ter ocorrido suicídio, é provável que o laudo não reforce que foi suicídio. Não é isso?

- Mas quando um perito tem convicção de que foi suicídio, ele costuma colocar no laudo a palavra suicídio?

- Eu não consigo me lembrar. É tanta coisa, sabe? Lamento muito não poder te ajudar.

- O senhor não se lembra de ter estado nesse local?

- Eu não me lembro de nada. (ARBEX, 2015, p.319)

A questão do silêncio recebe destaque na narrativa da autora, pois tanto quem foi opressor quanto quem foi oprimido durante os anos de chumbo no Brasil tem uma imensa dificuldade em comentar sobre o que vivenciou, sendo que o silêncio em forma de esquecimento pode surgir como uma maneira de se esquivar das responsabilidades por parte daqueles que apoiaram o regime militar, mas que ainda hoje possuem a obrigação de prestar contas à história e à memória do país. Assim, podemos perceber na narrativa de Arbex a tentativa de luta contra o esquecimento e de manutenção da memória a que se refere Gagnebin, já que a jornalista preocupou-se com a elucidação de um episódio sombrio da história do Brasil. Nesse sentido, também a autora tentou narrar o inenarrável, já que buscou reconstituir os últimos dias de vida, bem como as circunstâncias da morte de um preso político da ditadura militar brasileira que não sobreviveu ao regime para narrar sua experiência e, justamente por isso, não deve ser esquecido, pois os sobreviventes devem pelo menos tentar reconstituir parte de sua história, que é também a história de muitos outros brasileiros e brasileiras que viveram o período ditatorial brasileiro. Daniela Arbex reflete sobre essas questões, ao tomar consciência de que a singularidade da história de Milton e de sua família, na verdade, foi vivenciada por muitos outros brasileiros:

Ali, ouvindo o irmão do guerrilheiro, me dei conta de que estava junto a uma das milhares de famílias brasileiras que tiveram suas histórias atravessadas pela ditadura. Centenas de órfãos, pais, mães, esposas e amigos continuam a sofrer por 
décadas a fio diante de fatos propositalmente escondidos. Ninguém tem o direito de guardar silêncio sobre crimes contra a Humanidade. (ARBEX, 2015, p.341)

O trabalho de investigação de Arbex trouxe para o presente a história de um cidadão brasileiro que, além de morto, foi também esquecido pelo Estado. Coube à jornalista dar destaque à história que foi tratada por esse Estado com indiferença e esquecimento. Gagnebin (2009), refletindo sobre a figura do narrador a partir do ensaio O narrador de Benjamin, entende que a narração contemporânea parte das ruínas da narrativa, com o intuito de não deixar o passado cair no esquecimento. Dessa forma, a pesquisadora suíça entende o narrador enquanto um catador de sucata, alguém que recolhe os cacos e restos, para não deixar nada se perder. Podemos entender Cova 312 partindo dessa mesma concepção, na medida em que a jornalista e escritora buscou resgatar a história e a memória de um homem considerado invisível pelo Estado, e o faz através de sua narração. Sobre o que denomina narrador sucateiro, Gagnebin afirma:

Esse narrador sucateiro (o historiador também é um Lumpensammler) não tem por alvo recolher os grandes feitos. Deve muito mais apanhar tudo aquilo que é deixado de lado como algo que não tem significação, algo que parece não ter nem importância nem sentido, algo com que a história oficial não sabe o que fazer. (GAGNEBIN, 2009, p.54)

Daniela Arbex foi essa narradora sucateira ao compilar os testemunhos dos invisíveis para o Estado, aqueles que ficaram de fora da história oficial, que foram todos os militantes que vivenciaram o período da ditadura brasileira e que passaram a figurar em destaque em sua narrativa. $\mathrm{Na}$ esteira de Benjamin, Gagnebin tece considerações sobre o que ou quem estaria fora do discurso histórico, nomeando, com um sofrimento indizível oriundo das grandes guerras,

aquilo que não tem nome, aqueles que não têm nome, o anônimo, aquilo que não deixa nenhum rastro, aquilo que foi tão bem apagado que mesmo a memória de sua existência não subsiste - aqueles que despareceram tão por completo que ninguém lembra de seus nomes. Ou ainda: o narrador e o historiador deveriam transmitir o que a tradição, oficial ou dominante, justamente não recorda. Essa tarefa paradoxal consiste, então, na transmissão do inenarrável, numa fidelidade ao passado e aos mortos, mesmo - principalmente - quando não conhecemos nem seu nome nem seu sentido. (GAGNEBIN, 2009, p.54)

O militante Milton Santos foi tão bem apagado pelo Estado que após seu assassinato o corpo desapareceu, e seu paradeiro só foi descoberto trinta e cinco anos depois. Foi a fidelidade ao passado que motivou a jornalista e oportunizou esse resgate de memória no tempo presente, tanto da vida de Milton quanto também de parte da história do Brasil. Gagnebin trabalha com o conceito de rememoração para tratar da memória que está atrelada ao presente e que considera os lapsos e esquecimentos: 
Tal rememoração implica uma certa ascese da atividade historiadora que, em vez de repetir aquilo de que se lembra, abre-se aos brancos, aos buracos, ao esquecido e ao recalcado, para dizer, com hesitações, solavancos, incompletude, aquilo que ainda não teve direito nem à lembrança nem às palavras. A rememoração também significa uma atenção precisa ao presente, em particular a estas estranhas ressurgências do passado no presente, pois não se trata somente de não se esquecer do passado, mas também de agir sobre o presente. A fidelidade ao passado, não sendo um fim em si, visa à transformação do presente. (GAGNEBIN, 2009, p.55)

Cova 312 oportuniza uma série de reflexões sobre as relações entre o passado e o presente. A própria autora reflete sobre a importância do testemunho dos sobreviventes, e os ensinamentos que estes podem nos trazer, apontando para algumas influências do período da ditadura na contemporaneidade:

Conhecer os episódios de vida e de morte dos militantes políticos me deu a oportunidade de desvendar um Brasil que ainda teme os seus fantasmas e se acovarda diante do peso da culpa. Os sobreviventes têm muito a ensinar: convivem com suas sequelas e enfrentam a herança da violência para seguir em frente, mesmo sendo difícil se livrar do tormento da perseguição. Fazer silêncio diante de uma nação que foi esfacelada pela violência no passado e continua reproduzindo os métodos de tortura e exclusão do período do arbítrio é compactuar com crimes dos quais podemos nos tornar vítimas. Pior que isso: reeditar nas ruas do país marchas pela ordem clamando o retorno da ditadura é desconhecer os anos de sombra que envolveram o Brasil ou aceitar que a força supere o diálogo e o esforço histórico dos movimentos populares na busca por caminhos de paz. (ARBEX, 2015, p.335-336)

Os sobreviventes entrevistados por Arbex deram seus testemunhos possíveis, marcados por lapsos, medos, inseguranças e traumas. Isso não é pouco, pois contribuíram para que uma família descobrisse o destino final de um ente querido, e um dos muitos episódios de desaparecimento do período da ditadura militar brasileira fosse solucionado. A autora finaliza seu livro-reportagem ressaltando a necessidade da manutenção da busca por informações sobre os presos e desaparecidos políticos do período da ditadura brasileira:

Assim como os familiares de Milton puderam saber sobre a existência da Cova 312, onde o integrante do MNR foi sepultado, apontar o destino das ossadas de cada militante abatido e esclarecer as mortes ocorridas nos vinte e um anos de arbítrio é sanar uma dívida histórica do país com os seus filhos. Revolver o passado é vital para se fazer justiça e para consolidação do estado democrático de direito.

Punir ou perdoar? Enquanto o Brasil se divide entre a anistia e a imprescritibilidade dos crimes de tortura - o que os tornaria passíveis de responsabilização 
ainda hoje -, uma certeza se consolida: esquecer é impossível. E se centenas de brasileiros tiveram suas vozes silenciadas, nós continuaremos a lembrá-los, um a um, falando em seus nomes.

- Milton Soares de Castro!

- PRESENTE! (ARBEX, 2015, p.341-342)

A escrita da jornalista Daniela Arbex opera enquanto ato político, na medida em que desenterra parte da história do Brasil que foi sepultada juntamente com o corpo do militante político Milton. Os testemunhos dos sobreviventes contribuem para a reescrita da história e para o trabalho de rememoração, oportunizando a esse militante, e também à sua família, o direito à lembrança e à palavra, mesmo que através de outras vozes. Ao dar escuta a dezenas de mulheres e homens que vivenciaram o regime ditatorial brasileiro, Arbex também atua enquanto uma testemunha da história do Brasil, e o compilado de testemunhos, por ela organizados, resultam em uma narração que propicia a versão da história contada pelos vencidos, em uma busca constante pelo entendimento do passado no tempo presente, para que o passado não seja esquecido e nos traga ensinamentos na contemporaneidade. 


\section{REFERÊNCIAS}

AGAMBEN, Giorgio. O que resta de Auschwitz: o arquivo e a testemunha (Homo Sacer III). São Paulo: Boitempo, 2008.

ARBEX, Daniela. Cova 312. São Paulo: Geração Editorial, 2015.

BENJAMIN, Walter. Sobre o conceito de história. In: Magia e técnica, arte e política: ensaios sobre literatura e história da cultura. Obras Escolhidas Vol 1. Tradução Sergio Paulo Rouanet. São Paulo: Brasiliense, 1996.

COSSON, Rildo. Romance-reportagem: o gênero. Brasília: UNB, 2001.

GAGNEBIN, Jeanne Marie. Verdade e memória do passado; Memória, história, testemunho. In: Lembrar escrever esquecer. São Paulo: Editora 34, pp. 39-58, 2009.

LIMA, Edvaldo Pereira. Páginas ampliadas. O livro-reportagem como extensão do jornalismo e da literatura. São Paulo: Manole, 2004.

SELIGMANN-Silva, Márcio. Literatura e trauma. Pro-posições, Campinas, v. 13, n. 3 (39), set/dez, pp. 135-153, 2002.

SELIGMANN-Silva, Márcio. Narrar o trauma: escrituras híbridas das catástrofes. Gragoatá, Niterói, n. 24, pp. 101-117, 1. sem 2008. 